Luka JESENŠEK, Dejan VERČIČ, Luka KRONEGGER*

\title{
STRUKTURA SLOVENSKE POLITIČNE RAZPRAVE NA TWITTERJU OB VOLITVAH V EVROPSKI PARLAMENT**
}

\begin{abstract}
Povzetek. $Z$ metodami za analizo socialnih omrežij preučujemo strukturo slovenske politične razprave na spletnem družbenem omrežju Twitter pred volitvami $v$ Evropski parlament 2019. Opisujemo omrežje 2867 uporabnikov in 40670 objav (tvitov), središčne uporabnike, pretok informacij prek posredovanih objav (retvitov) in skupnosti uporabnikov. Med najaktivnejšimi uporabniki prevladujejo širši javnosti manj znani posamezniki, med najvplivnejšimi pa politične stranke, politiki in znane osebnosti. Vomrežju pretoka informacij se pojavljajo politično/mnenjsko homogene skupnosti uporabnikov, kar nakazuje na fragmentacijo mrežne javne sfere in polarizacijo slovenske spletne politične razprave. Rezultati ponujajo enega izmed prvih vpogledov $v$ pretok informacij med slovenskimi uporabniki Twitterja skozi prizmo fragmentacije družbenih omrežij.

Ključni pojmi: spletna družbena omrežja, Twitter, središčni uporabniki, fragmentacija, evropske volitve, analiza socialnih omrežij
\end{abstract}

\section{Uvod}

Pri preučevanju komuniciranja in odnosov $\mathrm{z}$ javnostmi je $\mathrm{v}$ zadnjih letih veliko pozornosti usmerjene $\mathrm{k}$ družbenim omrežjem, ki so postala pomembna platforma za javno in politično komuniciranje ter širjenje novic (Allcott in Gentzkow, 2017). Vendar pa z vidika komuniciranja ostajajo odprta vprašanja o naravi vse bolj globaliziranih in individualiziranih komunikacijskih omrežij (Castells, 2008). Nanje vplivajo nove tehnologije (Verčič et al., 2015) ter družbeni trendi, kot sta hipermodernost (Verhoeven et al., 2018) in medijizacija (Strömbäck in Esser, 2014). Tehnološke, medijske in družbene spremembe vplivajo tudi na javno sfero. Če so v 20. stoletju množični mediji nagovarjali enotno javnost (Habermas, 1989), dandanes

* Luka Jesenšek, doktorski študent, Fakulteta za družbene vede, Univerza v Ljubljani, Slovenija, dr. Dejan Verčič, redni profesor, Fakulteta za družbene vede, Univerza v Ljubljani, Slovenija; dr. Luka Kronegger, docent, Fakulteta za družbene vede, Univerza v Ljubljani.

** Izvirni znanstveni članek. DOI: 10.51936/tip.58.1.49-71 
mrežno povezani novi mediji ustvarjajo vsebine, namenjene množicam razpršenih, fragmentiranih javnosti, ki niso trajne strukture, pač pa se oblikujejo, povezujejo in razkrajajo glede na skupne interese njihovih članov (Bruns in Highfield, 2016). Vrstijo se opozorila, da se na spletnih družbenih omrežjih namesto razširjene javne razprave državljani raje zapirajo v skupnosti s podobnimi pogledi (Pariser, 2011; Sunstein, 2017), to pa omejuje izpostavljenost različnim mnenjem. Tehnološka arhitektura spletnih družbenih omrežij še dodatno spodbuja izpostavljenost vsebinam po svojem izboru (Spohr, 2017), kar naj bi prav tako povečevalo polarizacijo. Vendar pa po drugi strani ugotavljamo, da so lahko uporabniki družbenih omrežij izpostavljeni celo večji raznolikosti vsebin kot neuporabniki (Barberá, 2014; Bakshy et al., 2015; Duggan in Smith, 2016), zaradi česar naj bi bila novodobna zaskrbljenost nad učinki fragmentacije in polarizacije pretirana (Guess et al., 2017; Bruns, 2017). Preučevanje omenjenih procesov je še posebej zanimivo v okviru političnih razprav na spletnem družbenem omrežju Twitter, saj naj bi ta s svojo infrastrukturo ponujal nove možnosti politične participacije. Čeprav naj bi spletna družbena omrežja opolnomočila državljane, se je kmalu pokazalo, da navkljub vključujoči arhitekturi še zmeraj v veliki meri odsevajo obstoječe družbene strukture in razmerja moči (Stromer-Galley, 2017). Politiki, mediji in drugi predstavniki »elit« naj bi tako tudi v komunikaciji na Twitterju uživali dominantne pozicije (Ausserhofer in Maireder, 2013).

Dosedanje razumevanje področja je pretežno vezano na raziskave iz ZDA in zahodne Evrope, vendar pa veljavnost izsledkov znotraj manjših spletnih skupnosti ni samoumevna. To je še posebej očitno pri opazovanju političnih razprav, ki so na Twitterju pogosto strukturirane glede na ideološka prepričanja uporabnikov (Barberá et al., 2015), zaradi česar je njihova struktura lahko $v$ veliki meri odvisna od družbenega in političnega konteksta. Raziskave komuniciranja na spletnih družbenih omrežjih so pogosto postavljene $\mathrm{v}$ izrazito polarizirano okolje (npr. glasovanje o britanskem izstopu iz Evropske unije ali predsedniške volitve v ZDA); politična razprava $v$ slovenskem predvolilnem kontekstu pa obsega večje število akterjev, kandidatov in političnih strank, ki zastopajo širšo paleto pogledov. Študija primera spletne razprave pred evropskimi volitvami v Sloveniji kot mladi demokraciji, eni izmed novejših članic EU, z relativno majhnim številom prebivalcev in povprečno uporabo informacijskih in komunikacijskih tehnologij ponuja zanimivo primerjavo z večjimi okolji, v katerih so obravnavane teme pogosteje preučevane.

Komuniciranja na spletnih družbenih omrežjih ne moremo razumeti le kot eno- ali dvosmerni proces, pač pa kot dinamičen proces ustvarjanja pomena, ki nenehno poteka $\mathrm{v} v$ seh smereh med akterji, ki se izmenjujejo $\mathrm{v}$ vlogah pošiljateljev in prejemnikov sporočil (van Ruler, 2018). V sodobni 
komunikacijski krajini so sporočila, kanali, deležniki in posamezniki medsebojno povezani s širokim naborom odnosov. Te lahko opišemo z mrežnim pristopom k preučevanju komuniciranja (O'Connor in Shumate, 2018), ki skupaj z dosegljivimi digitalnimi podatki o uporabi spletnih družbenih omrežij ponuja nove možnosti za ocenjevanje in merjenje komunikacijskih aktivnosti in njihovih učinkov (Holtzhausen in Zerfass, 2015). Metode za analizo socialnih omrežij skupaj z velikimi količinami digitalnih podatkov omogočajo vpogled v strukturo komuniciranja na spletnih družbenih omrežjih. Pričujoča raziskava s pomočjo analize omrežij preučuje komuniciranje, interakcije in širjenje vsebin med slovenskimi uporabniki Twitterja $\mathrm{v}$ kontekstu politične razprave pred volitvami v Evropski parlament leta 2019. Primerljivost s tujimi raziskavami odgovarja na pozive po preučevanju komuniciranja in širjenja vsebin na spletnih družbenih omrežjih v različnih državah in družbenih ter jezikovnih kontekstih (Bennett in Livingston, 2018), rezultati pa ponujajo enega izmed prvih vpogledov v pretok informacij na slovenskem Twitterju skozi prizmo fragmentacije družbenih omrežij.

Članek je razdeljen na dva dela. V prvem se posvečamo teoretični razlagi procesov komuniciranja na spletnih družbenih omrežjih, predvsem Twitterju, v nadaljevanju pa predstavimo empirično študijo komuniciranja na Twitterju znotraj slovenskega političnega prostora in njene ključne ugotovitve.

\section{Teoretični okvir in pregled literature}

\section{Twitter in politična participacija}

Medtem ko se klasični mediji soočajo z upadom dosega, so spletna družbena omrežja postala pomembna platforma za javno komuniciranje in širjenje novic. S širjenjem uporabe interneta in digitalnih tehnologij tudi v Sloveniji postajajo vse bolj priljubljena, njihova uporaba pa sledi povprečju Evropske unije. Leta 2019 je v Sloveniji na spletnih družbenih omrežjih aktivno sodelovalo 52\% oseb, starih 16-74 let (Statistični urad Republike Slovenije, 2019), v EU 54\% (Eurostat, 2019). Po podatkih raziskovalne agencije Valicon (2020) ima 82\% prebivalcev Slovenije v starosti od 16 do 74 let odprt profil na vsaj enem družbenem omrežju. Na področju javnega in političnega komuniciranja je eno izmed najpomembnejših omrežij postal Twitter, ki omogoča objavljanje kratkih sporočil dolžine do 280 znakov, imenovanih tviti, sporočila pa lahko poleg besedila vsebujejo tudi povezave do spletnih strani in multimedijske vsebine. Objavljena sporočila se pogosto razširjajo z možnostjo retvita (posredovane objave), ki omogoča, da uporabnik sporočilo drugega uporabnika deli s svojimi sledilci. V primerjavi z drugimi spletnimi družbenimi omrežji, predvsem popularnejšim Facebookom, 
je Twitter veliko bolj odprta platforma. Večina objavljenih vsebin je javno dostopnih in vidnih tudi tistim, ki na omrežju nimajo ustvarjenega profila. Prav tako ustvarjanje povezav med uporabniki ni recipročno - uporabnik lahko sledi drugemu uporabniku in spremlja njegove objave, ne da bi ta mogel povezavo potrditi. Zaradi teh lastnosti je Twitter hitro po nastanku leta 2006 postal ena izmed najbolj priljubljenih platform za javno in politično komuniciranje; tako je tudi v Sloveniji, kjer je imel leta 2019208.500 uporabnikov (Valicon, 2020). Uporablja jo večina predstavnikov politike, medijev in civilne družbe, pa tudi državljani, ki sodelujejo v spletnih razpravah, izražajo svoja mnenja ali pa samo spremljajo objave drugih akterjev. $S$ tem je Twitter postal tudi pomembno orodje politične participacije. Ta v osnovi predstavlja komunikacijski proces, s katerim državljani politikom sporočajo svoje želje (Brezovšek, 1995). Nanaša se na »vključenost posameznika, skupin, organiziranih skupnosti v zadeve javnega značaja /.../, z razširjenostjo spletnih medijev in digitalnih tehnologij pa postaja vse bolj tehnološko posredovana (Oblak, 2014: 1176). V zadnjih letih se veliko raziskav posveča preučevanju spletne politične participacije $z$ uporabo dostopnih digitalnih podatkov o uporabnikih spletnih družbenih omrežij, saj slednja postajajo novodoben prostor političnega udejstvovanja. S svojo infrastruk-

52 turo državljanom ponujajo nove možnosti politične participacije, njihova odprta in interaktivna narava pa omogoča izražanje mnenj in sodelovanje v političnih razpravah ter predstavlja protiutež tradicionalnim modelom komuniciranja »od zgoraj navzdol«. Politična participacija na Twitterju je najpogosteje razumljena kot objavljanje in deljenje sporočil, ki vsebujejo $s$ politiko povezane ključne besede ali ključnike (Jungherr, 2015). Pogosto je preučevana ob večjih političnih dogodkih, kot so npr. nacionalne volitve (Bracciale et al., 2018), referendumi (Arlt et al., 2019), menjave oblasti (Soares et al., 2018), ter ob širših družbenih razpravah o odmevnih temah, kot npr. pravice temnopoltih (Stewart et al., 2017) ali prostotrgovinski sporazumi in schengensko območje (Ruiz-Soler, 2018).

\section{Središčni uporabniki}

Za razumevanje politične participacije na Twitterju je zelo primeren mrežni pristop, ki namesto analizi posamičnih sporočil pozornost posveča uporabnikom in njihovim povezavam v omrežju. Izpostavljenost sporočilom s politično vsebino in doseg sporočanja sta namreč odvisna od uporabnikovega družbenega omrežja - oseb in organizacij, s katerimi je povezan (Himelboim et al., 2013). Pri preučevanju razprav na Twitterju zato posebno pozornost namenjamo t.i. središčnim uporabnikom, to so uporabniki, ki imajo zaradi svojega položaja v omrežju nadpovprečen vpliv na širjenje informacij. Participacija na Twitterju je med udeleženci spletne razprave 
pogosto neenakomerno razporejena, pri čemer je značilno, da manjšina uporabnikov prispeva k produkciji ali deljenju večine sporočil. Raziskovalci govorijo o delitvi na najaktivnejših $10 \%$ ali celo $1 \%$ nadpovprečno aktivnih uporabnikov, ki prispevajo enako ali celo večjo količino vsebin kot preostala večina - Graham in Wright (2014) jih imenujeta "superudeleženci«. Za preučevanje politične participacije na Twitterju je poleg aktivnosti uporabnikov pomemben tudi njihov vpliv, ki ga lahko operacionaliziramo na različne načine. Analiza omrežij ponuja mere središčnosti, s katerimi lahko kvantitativno opišemo vpliv posameznih enot v komunikacijskem procesu. Vpliv se lahko na Twitterju izrazi s številom prejetih povezav - sklepamo lahko, da so vplivnejši tisti uporabniki, ki jih drugi člani pogosto omenjajo, ali pa uporabniki, katerih sporočila so bila večkrat deljena (Dang-Xuan et al., 2013; Dubois in Gaffney, 2014). Vpliv in participacija na Twitterju nista nujno povezana - nekateri ugotavljajo, da je aktivnejša participacija povezana s povečano vidnostjo (Bastos et al., 2013), drugi pa sklepajo, da najaktivnejši uporabniki zaradi deljenja velike količine vsebin niso nujno tudi vidnejši ali vplivnejši (Cha et al., 2010; Bracciale et al., 2018). Preučevanje središčnih uporabnikov je pomembno, saj imajo ti zaradi dosega in povezav velik vpliv na širjenje vsebin (Goel et al., 2015). Spletna družbena omrežja vsakomur omogočajo objavljanje informacij in mnenj, s čimer naj bi zmanjšala vlogo tradicionalnih nosilcev vpliva (van Dijk in Hacker, 2018), vendar pa je vedenje o tem, kakšna je vloga različnih akterjev, omejeno (Maireder et al., 2017). Navkljub vključujoči arhitekturi spletnih družbenih omrežij, ki naj bi opolnomočila državljane in omogočila globalno demokratizacijo, se je kmalu izkazalo, da ta še zmeraj v veliki meri odsevajo obstoječe družbene strukture in razmerja moči (Stromer-Galley, 2017). Politiki, mediji in drugi predstavniki »elit« tudi v komunikaciji na Twitterju uživajo dominantne pozicije in se pogosto uvrščajo med najvplivnejše uporabnike (Ausserhofer in Maireder, 2013). Po drugi strani pa lahko središčna mesta v komunikaciji na Twitterju zavzemajo tudi širši javnosti neznani uporabniki, ki tak status uspejo pridobiti z aktivno participacijo in pogostim deljenjem vsebin (RuizSoler, 2018). V kontekstu polarizirane politične razprave je status središčnih uporabnikov pogosto omejen na posamezne skupnosti v omrežju, znotraj katerih si posamezniki pridobijo vpliv z deljenjem vsebin, ki ustrezajo pogledom njihovih članov (Soares et al., 2018).

\section{Skupnosti uporabnikov in fragmentacija javnosti}

V hipermodernem, medijiziranem (Strömbäck in Esser, 2014) svetu in mrežno povezanih medijih (Klinger in Svensson, 2015) je struktura javne sfere - v primerjavi s tisto, ki jo v zlati dobi množičnih medijev opisuje Habermas (1989) - veliko bolj kompleksna, dinamična in večplastna. 
Mnogi govorijo o transformaciji in fragmentaciji sodobne, mrežne javne sfere (Benkler, 2006) v splet različnih, a med seboj povezanih javnosti, ki niso trajne strukture, pač pa se oblikujejo, povezujejo in razkrajajo glede na skupne interese njihovih članov (Bruns in Highfield, 2016). Oblikujejo se okoli različnih tem, dogodkov in idej, prek različnih komunikacijskih platform, pri čemer članstvo v eni izmed njih ne izključuje sodelovanja v drugih. Pariser (2011) tako opozarja, da zaradi fragmentirane razprave spletnih družbenih omrežij ne moremo dojemati kot javne sfere, pač pa kot skupek manjših, strnjenih in pogosto nepovezanih skupnosti. Slednje lahko opazujemo tudi na Twitterju, kjer uporabniki, vključeni v razpravo o določenih temah, tvorijo t.i. ad hoc javnosti (Bruns in Highfield, 2016). Ne gre za trajne strukture, pač pa za dinamične skupnosti, ki se oblikujejo na podlagi skupnega interesa uporabnikov in se spreminjajo skozi čas. Člani takšnih skupnosti na Twitterju preferenčno komunicirajo med seboj, zato jih lahko na podlagi komunikacijskih vzorcev odkrijemo z analizo socialnih omrežij (Rasmussen, 2016). Povezovanje podobno mislečih uporabnikov vodi do oblikovanja ideološko homogenih skupnosti, kar omejuje izpostavljenost različnim mnenjem in povečuje polarizacijo (Dylko et al., 2017). Skupnosti uporabnikov so tako vse bolj ideološko obarvane in razdeljene glede na odnos do določene teme ali lastnosti, npr. rase, državljanstva, politične opredelitve itd. (van Dijk in Hacker, 2018). Pogosta so opozorila, da porast tesno povezanih, ideološko homogenih skupnosti na spletnih družbenih omrežjih vodi do intenzivnejše in vse bolj problematične polarizacije celotne družbe (Sunstein, 2017). ${ }^{1}$ Polarizirane skupnosti uporabnikov lahko opazujemo v političnih razpravah na Twitterju; Smith in drugi npr. govorijo o "polarizirani množici«, tipični strukturi spletne razprave, ki jo pogosto zasledimo $\mathrm{v}$ političnih kontekstih in $\mathrm{v}$ kateri so uporabniki razdeljeni $\mathrm{v}$ strnjene skupine z malo povezavami med njimi (Smith et al., 2014). Struktura omrežja na Twitterju vpliva tudi na zmožnost širjenja vsebin (Harrigan et al., 2012) - ljudje raje beremo in delimo, kar se sklada z našimi prepričanji (Bakshy et al., 2015), zato se takšne vsebine hitro delijo znotraj ideološko homogene skupnosti, veliko težje pa se razširijo onkraj njenih meja. Različni uporabniki tako prejemajo različne informacije iz različnih virov;

1 Vzroke nekateri pripisujejo tehnološkim in tržnim dejavnikom - večina javnega komuniciranja danes poteka na platformah, ki jih obvladujejo globalni tehnološki monopoli; ti z algoritmičnim razvršča njem in personalizacijo uporabniku prikazujejo vsebine glede na njegove vedenjske vzorce, omrežja prijateljev in preteklo ravnanje ter jih s tem obkrožajo z enako mislečimi; na pritegovanje pozornosti vezani poslovni modeli pa spodbujajo širjenje ekstremnih vsebin (Pariser, 2011; Sunstein, 2017). Algoritmično razurščanje vsebin in poslovni modeli platform naj bi vodili do demokratičnega deficita mrežne javne sfere (Sekloča, 2020). Vendar pa tehnološko determiniran pogled spregleda vrsto psiholoških in družbenih dejavnikov, zaradi katerih se ljudje raje družimo s sebi podobnimi in dajemo prednost vsebinam, ki se skladajo z našimi pogledi (Miller et al., 2001). To seveda ni nov pojav, obstaja pa možnost, da danes s podatki, ki nam jih ponujajo spletna družbena omrežja, te procese lažje zaznamo in preučujemo. 
zaradi tega se $\mathrm{v}$ fragmentirani javni sferi težje soočajo alternativna mnenja in pogledi (V ke-Freiberga et al., 2013; Sekloča, 2020). To potrjujejo raziskave širjenja vsebin $\mathrm{v}$ izrazito polariziranih političnih kontekstih, kot so predsedniške volitve v ZDA (Shin et al., 2017) na Twitterju ali referendum o britanskem izstopu iz Evropske unije (Del Vicario et al., 2017) na Facebooku, ki nakazujejo, da se večina vsebin kljub velikemu številu delitev ne razširja po celotnem omrežju, temveč pretežno znotraj mnenjsko homogenih skupnosti uporabnikov (Del Vicario et al., 2016). Vendar pa po drugi strani nekateri ugotavljajo, da so uporabniki družbenih omrežij izpostavljeni celo večji raznolikosti vsebin kot neuporabniki (Barberá, 2014; Bakshy et al., 2015; Duggan in Smith, 2016); tudi politične debate na Twitterju naj bi bile pluralistične in naj bi omogočale izmenjavo mnenj med različno mislečimi uporabniki (Arlt et al., 2019). Zaradi tega naj bi bila zaskrbljenost nad negativnimi učinki fragmentacije in polarizacije pretirana (Guess et al., 2017; Bruns, 2017); izrazito polarizirano in fragmentirano okolje pa naj ne bi odražalo izkušnje povprečnega uporabnika spletnih družbenih omrežij (Neudert in Marchal, 2019).

\section{Raziskovalna vprašanja}

Dosedanje razumevanje področja je pretežno vezano na raziskave iz ZDA in zahodne Evrope, vendar pa veljavnost izsledkov znotraj manjših spletnih skupnosti ni samoumevna; slednje je še posebej očitno pri opazovanju političnih razprav, saj so le-te odvisne od družbenega in političnega konteksta. Študija primera spletne razprave pred evropskimi volitvami v Sloveniji ponuja zanimivo primerjavo z večjimi okolji, v katerih so obravnavane teme pogosteje preučevane. Glede na predstavljene teoretične zasnove $\mathrm{z}$ analizo komuniciranja na Twitterju preučujemo, kako je bila strukturirana slovenska spletna razprava pred volitvami v Evropski parlament in v kolikšni meri je bila fragmentirana.

RV 1: Kakšen je obseg slovenske politične razprave na Twitterju?

Pri tem se osredotočamo na tri podvprašanja. PV 1.1: Koliko uporabnikov v njej sodeluje? PV 1.2: Kdo so najaktivnejši uporabniki? PV 1.3: Kdo so najvplivnejši uporabniki?

RV 2: Ali je slovenska politična razprava na Twitterju razdeljena na posamezne skupnosti?

Pri tem se osredotočamo na dve podvprašanji. PV 2.1: Kakšne so značilnosti teh skupnosti, v kolikor obstajajo, glede na uporabnike? PV 2.2: Kakšne so značilnosti teh skupnosti, v kolikor obstajajo, glede na vsebine, ki se znotraj njih razširjajo? 


\section{Metodološki pristop}

Metodologija sledi literaturi, ki za proučevanje spletnega komuniciranja priporoča mešan metodološki pristop (Jungherr, 2015; Howard et al., 2017). Raziskovalnih vprašanj se lotevamo: (1) z metodami za analizo socialnih omrežij, (2) s kvantitativno analizo deljenih vsebin in (3) s kvalitativno analizo izbranih vsebin. Kvalitativna analiza pripomore k razumevanju in kontekstualizaciji kvalitativnih podatkov.

\section{Zbiranje podatkov}

Bazo relevantnih tvitov smo na podlagi nabora ključnih besed zbrali z uporabo Twitter Streaming API in orodja DMI-TCAT, ki omogoča zajem in neprekinjeno shranjevanje podatkov (Borra in Rieder, 2014). Za ključne besede smo uporabili najpogostejše ključnike, uporabljene v spletni razpravi o evropskih volitvah; ker pa veliko uporabnikov v tvitih ne uporablja ključnikov, smo dodali še besedo "volitve " v različnih sklonih. Uporabljen nabor ključnih besed za zbiranje podatkov je obsegal: \#epvolitve, \#epvolitve19, \#epvolitve2019, \#euvolitve, \#euvolitve19, \#euvolitve2019, \#volitve19,

56 \#volitve2019, \#evropskevolitve, \#tokratgremvolit, volitve, volitev, volitvam, volitvah, volitvami. Zbiranje podatkov je potekalo v obdobju enega meseca pred evropskimi volitvami, in sicer med 28. aprilom in 28. majem 2019. V bazo podatkov so vključeni vsi tviti, ki so 1) bili objavljeni v času zajema podatkov in so 2) vsebovali vsaj eno izmed ključnih besed ali pa je vsaj eno izmed njih vsebovala vsebina URL-povezave, vključena v tvitu. Iz zbranih podatkov smo ročno odstranili tvite, ki so se nanašali na druge teme (npr. volitve v drugih državah). Končna baza podatkov obsega 40670 tvitov in 2854 uporabnikov.

\section{Analiza omrežja}

Za analizo omrežja smo iz zbranih podatkov ustvarili omrežje retvitov, ki prikazuje tok informacij in širjenje vsebin v družbenem omrežju. Pri odkrivanju središčnih uporabnikov smo uporabili dve osnovni meri središčnosti, in sicer vhodno (in-degree) in izhodno (out-degree) stopnjo. Središčnost se nanaša na položaj uporabnika $v$ omrežju, zaradi katerega ima ta velik vpliv na pretok informacij (Ghajar-Khosravi in Chignell, 2017). Vhodna stopnja je mera središčnosti, ki pokaže, koliko povezav poteka proti določeni enoti v omrežju. Ker so v opazovanem omrežju povezave med enotami retviti, so enote $z$ visoko vhodno stopnjo uporabniki, katerih sporočila so bila največkrat retvitana. Pogosto retvitana sporočila lahko dosežejo večje število ljudi, tudi tistih izven kroga sledilcev avtorja sporočila, zato sklepamo, da 
so takšni uporabniki med bolj vplivnimi (Dang-Xuan et al., 2013; Dubois in Gaffney, 2014). Izhodna stopnja na drugi strani pokaže, kateri uporabniki so najpogosteje objavljali in retvitali druga sporočila oz. so bili pri širjenju sporočil najaktivnejši. Mera je povezana s konceptom t.i. superudeležencev (Graham in Wright, 2014), uporabnikov, ki nadpovprečno sodelujejo pri širjenju sporočil. Analizo podatkov smo opravili v programskem jeziku Python, za odkrivanje skupnosti smo uporabili algoritem Louvain (Blondel et al., 2008). Iz zajetih sporočil smo s programsko skripto izluščili in razširili URL-povezave deljenih medijskih vsebin, znotraj posameznih skupnosti pa opravili kvantitativno in kvalitativno analizo najpogosteje deljenih vsebin, uporabljenih ključnikov in najvplivnejših uporabnikov. Vizualizacijo omrežja retvitov smo ustvarili s pomočjo progama Gephi (Bastian et al., 2009) in algoritma Force Atlas 2 (Jacomy et al., 2014).

\section{Rezultati}

V analizo je zajetih 40670 tvitov 2854 uporabnikov, objavljenih v mesecu pred volitvami v Evropski parlament 26. maja 2019 (Tabela 1). Večina (69\%) zajetih tvitov predstavlja retvite (posredovane objave), $44 \%$ jih vključuje ključnike (\#), 34\% tvitov vsebuje URL-povezave do spletnih strani. Največ tvitov je bilo objavljenih na dan volitev, opazne poraste pa je mogoče zaslediti ob predvolilnih soočenjih kandidatov (Slika 1$)^{2}$ Število aktivnih uporabnikov in poslanih tvitov po dnevih počasi narašča do volitev, potem pa hitro upade; kar je značilna distribucija za napovedane dogodke (Lehmann et al., 2012).

\section{Tabela 1: ANALIZIRANE OBJAVE (TVITI) NA TEMO EVROPSKIH VOLITEV V SLOVENIJI}

\begin{tabular}{|l|c|}
\hline Št. Tvitov & $\mathbf{4 0 6 7 0}$ \\
\hline Śt. Uporabnikov & $\mathbf{2 8 5 4}$ \\
\hline Št. tvitov, ki vključujejo URL-povezave & $13780(34 \%)$ \\
\hline Št. tvitov, ki vključujejo ključnike (\#) & $19688(44 \%)$ \\
\hline Št. tvitov, ki vključujejo multimedijsko vsebino & $14255(35 \%)$ \\
\hline Št. retvitov (RT) & $28041(69 \%)$ \\
\hline
\end{tabular}

Vir: Lastni prikaz.

2 Vmesni dnevni porasti števila objavljenih tvitov na temo evropskih volitev ustrezajo datumom odmevnejših predvolilnih televizijskih soočenj (9. 5., 16. 5., 20. 5. in 23. 5.); ključnik \#soočenje je prav tako med najpogosteje uporabljenimi ključniki v zajeti bazi podatkov. 
Slika 1: AKTIVNI UPORABNIKI (RDEČE) IN OBJAVLJENI TVITI (MODRO) V OPAZOVANEM ČASOVNEM OBDOBJU

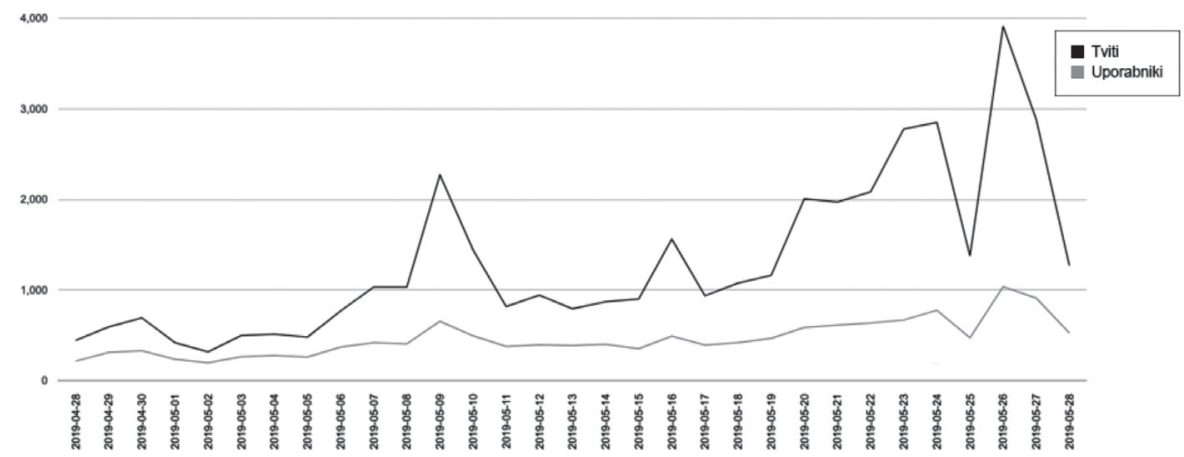

Vir: Analiza orodja DMI-TCAT in lastni prikaz.

\section{Središčni uporabniki}

Pri središčnih uporabnikih se osredotočamo na najaktivnejše in najvplivnejše uporabnike v opazovanem omrežju. Med najaktivnejšimi uporabniki (največ objavljenih tvitov - Tabela 2) je kar nekaj v javnem življenju bolj ali manj neznanih oseb. Izmed politikov se na seznam desetih najaktivnejših uporabnikov uvršča zgolj Janez Janša. Najaktivnejši uporabnik po številu objavljenih sporočil je @hladnikp, ki je v opazovanem obdobju objavil 701 tvit. V povprečju je vsak uporabnik objavil 14 tvitov, 1131 uporabnikov pa je v opazovanem obdobju objavilo zgolj enega. Razporeditev objavljenih sporočil sledi t.i. distribuciji dolgega repa (Graf 1) z nekaj zelo aktivnimi uporabniki in pasivnejšo večino.

Tabela 2: NAJAKTIVNEJŠI UPORABNIKI (ŠTEVILO OBJAVLJENIH TVITOV)

\begin{tabular}{|l|c|c|}
\hline Uporabnik & $\begin{array}{c}\text { Št. objavljenih tvitov } \\
\text { (izhodna stopnja) }\end{array}$ & Delež retvitov \\
\hline Hladnikp & 701 & $98 \%(686)$ \\
\hline FrancHimelrajh & 658 & $99 \%(655)$ \\
\hline JoAnnaOfArc1 & 546 & $90 \%(491)$ \\
\hline MarijaSoba & 538 & $99 \%(533)$ \\
\hline Bdarja & 497 & $93 \%(461)$ \\
\hline KatarinaUrankar & 453 & $100 \%(453)$ \\
\hline alojztetickovi3 & 440 & $94 \%(414)$ \\
\hline Carin2013 & 407 & $97 \%(396)$ \\
\hline JjansaSDS & 391 & $96 \%(376)$ \\
\hline Margu501 & 336 & $95 \%(318)$ \\
\hline
\end{tabular}

Vir: Lastni prikaz. 
Graf 1: DISTRIBUCIJA AKTIVNOSTI UPORABNIKOV GLEDE NA ŠTEVILO POSLANIH TVITOV

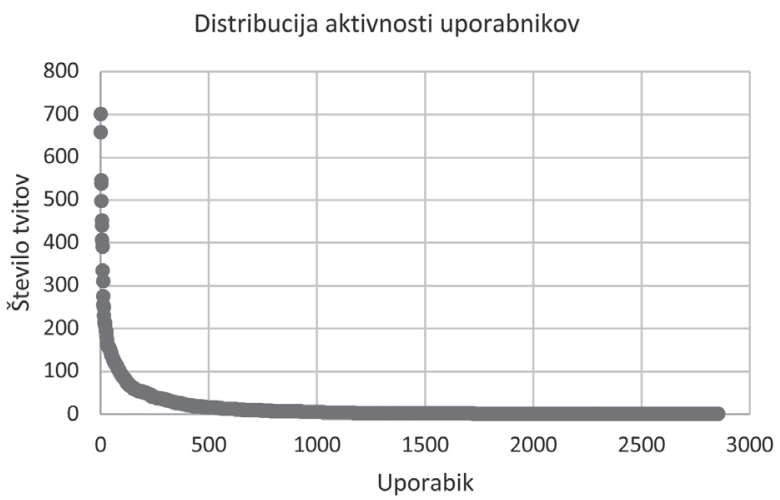

Vir: Lastni prikaz.

Najpogosteje retvitan uporabnik (mera središčnosti glede na vhodno stopnjo) je profil stranke SDS (@strankaSDS); njena sporočila so bila vopazovanem obdobju skupno retvitana 310-krat. V primerjavi z najaktivnejšimi je med najpogosteje retvitanimi uporabniki več politikov in drugih javno poznanih oseb (Tabela 3). Uporabniki, ki so v opazovanem obdobju objavljali največ, po večini niso hkrati tudi med najbolj retvitanimi, kar nakazuje, da participacija ni neposredno povezana z vplivom - tisti, ki so v spletni razpravi najaktivnejši, zaradi tega niso nujno tudi vidnejši ali vplivnejši.

Tabela 3: NAJVPLIVNEJŠI UPORABNIKI (NAJPOGOSTEJE RETVITANI)

\begin{tabular}{|l|c|}
\hline Uporabnik & $\begin{array}{c}\text { Stevilo prejetih retvitov } \\
\text { (vhodna stopnja) }\end{array}$ \\
\hline strankaSDS & 310 \\
\hline bojanpozar & 264 \\
\hline JJansaSDS & 199 \\
\hline metkav1 & 190 \\
\hline Dkopse & 177 \\
\hline Libertarec & 142 \\
\hline Mrevlje & 129 \\
\hline Jocarules & 127 \\
\hline Klavdyop & 119 \\
\hline Jozebiscak & 119 \\
\hline
\end{tabular}

Vir: Lastni prikaz. 


\section{Skupnosti v omrežju}

Za preučevanje komunikacijskih vzorcev in pretoka informacij smo iz zbranih podatkov ustvarili omrežje retvitov. V njem smo s pomočjo algoritma Louvain odkrili 49 skupnosti uporabnikov. Algoritem identificira skupnosti na podlagi povezav; enote, ki več komunicirajo med seboj, so razvrščene v isto skupnost (Himelboim et al., 2013). Večkratne iteracije algoritma proizvedejo konsistentne rezultate, kar nakazuje, da v omrežju obstajajo jasno določene skupnosti, ustvarjene na podlagi komunikacijskih vzorcev med uporabniki. Pet največjih skupnosti, uporabljenih v analizi, zajame $92 \%$ vseh uporabnikov. Ostale, manjše skupnosti obsegajo le nekaj izoliranih uporabnikov, ki so komunicirali zgolj med seboj in niso imeli vidnejših povezav z drugimi deli omrežja.

Podrobneje smo analizirali pet največjih skupnosti in vsebine, ki se $\mathrm{v}$ njih razširjajo. Znotraj skupnosti smo poiskali (1) najvidnejše uporabnike in (2) najpogosteje deljene vsebine - ključnike in povezave na spletne strani (Tabela 4). Opazovane skupnosti se med seboj razlikujejo v številu članov, njihovem položaju v omrežju, intenzivnosti komuniciranja, deljenih vsebinah in ideoloških pogledih:

60 - Skupnost 1 je s 846 člani (39,3\% vseh uporabnikov) največja skupnost v omrežju. Med najvidnejšimi člani so osrednji mediji, institucije in levo/ levosredinsko usmerjene politične stranke. Med najpogosteje uporabljenimi ključniki so oznake iz kampanj političnih strank SAB in SD ter Alde. Med najpogosteje deljenimi URL-povezavami prevladujejo povezave do osrednjih medijev (Večer, RTV, STA, Delo, Siol, 24ur).

- Skupnost 2 šteje 391 oz. 18,2\% vseh uporabnikov. Med najvidnejšimi uporabniki prevladujejo politiki in simpatizerji stranke SDS, oznake kampanje SDS so tudi med najpogosteje uporabljenimi ključniki. Med najpogosteje deljenimi URL-povezavami prevladujejo povezave do medijev nova24tv.si, sds.si in demokracija.si.

- Skupnost 3 šteje 563 članov oz. 26,1\% vseh uporabnikov. Med najvidnejšimi uporabniki so Bojan Požar, Tomaž Štih, Matej Lahovnik, Vili Kovačič, Lucija Ušaj. Med najpogosteje uporabljenimi ključniki so oznake kampanje SDS ter medijev Bojana Požarja. Najpogosteje deljene so povezave na spletne strani nova24tv.si, demokracija.si, 24 ur.com, rtvslo.si, pozareport. si, reporter.si.

- Skupnost 4 šteje 138 članov oz. 6,4\% vseh uporabnikov. Najvidnejši člani vključujejo predstavnike stranke NSi in novinarje, med najpogosteje uporabljenimi ključniki so oznake kampanje stranke NSi in EPP. Med deljenimi povezavami prevladujejo mediji demokracija.si, rtvslo.si, 24 ur. com, finance.si, domovina.je. 


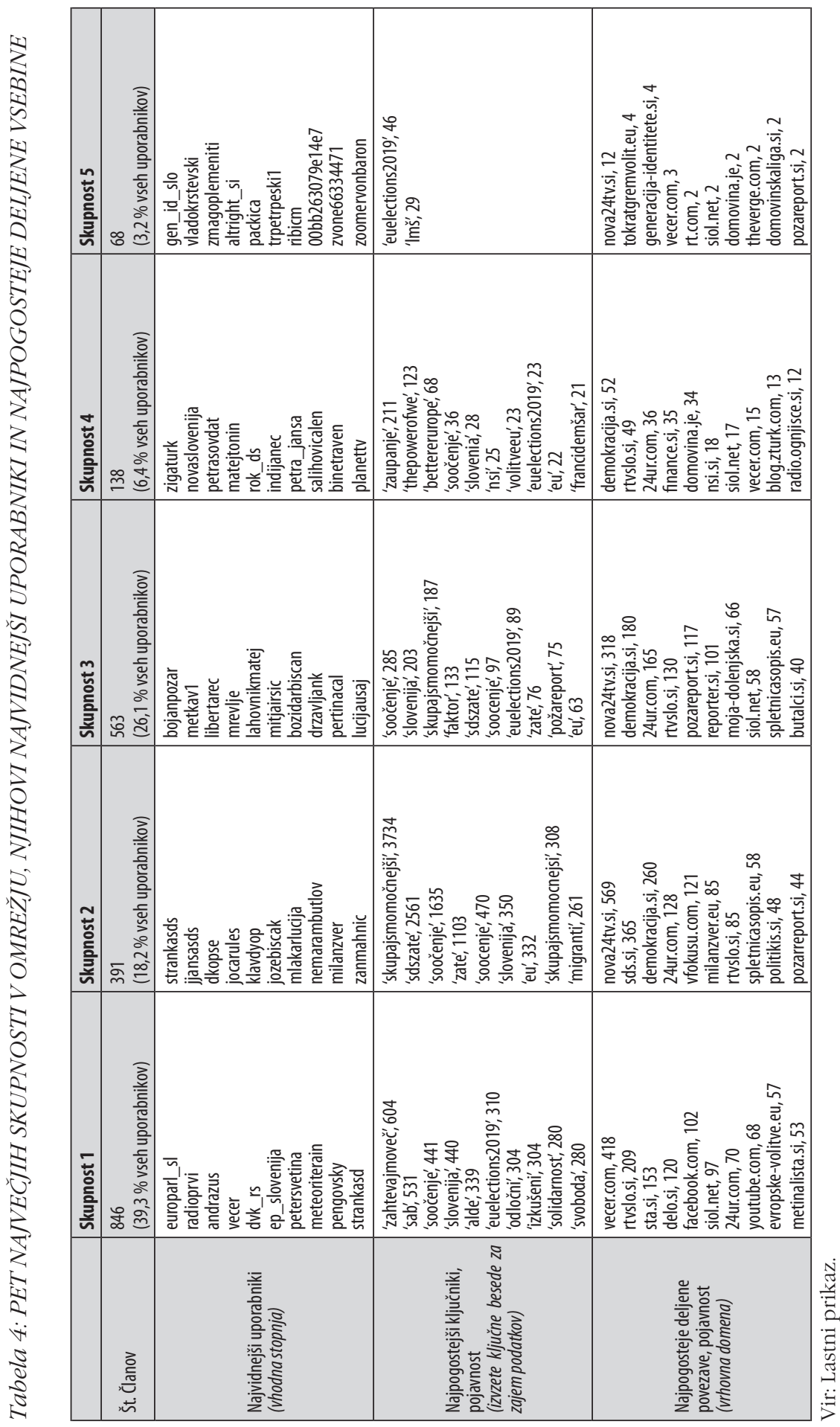


- Skupnost 5 šteje 68 članov oz. 3,2\% vseh uporabnikov. Glede na vsebine in člane manj homogena skupnost, med vidnejšimi uporabniki so simpatizerji gibanja Generacija identitete in altright, pa tudi politik Zmago Jelinčič ter skupina makedonskih profilov, namenjenih politični propagandi, ki kažejo na veliko stopnjo usklajenosti sporočil in avtomatizacije (boti). Slednji so izolirani in imajo povezave zgolj z enim članom celotnega opazovanega omrežja. Med najpogosteje deljenimi povezavami so nova24.si, tokratgremvolit.eu in ganeracija-identitete.si.

Vizualizacija omrežja retvitov (Slika 2) prikazuje položaj posameznih uporabnikov $\mathrm{v}$ omrežju in povezave $\mathrm{z}$ drugimi uporabniki glede na njihove vzorce komuniciranja. Uporabniki, ki so med seboj tesneje povezani, so prikazani bližje skupaj. Točke predstavljajo uporabnike, velikost točk njihov vpliv, povezave med točkami deljenje vsebin (retvit). Omrežje je usmerjeno, kar pomeni, da lahko razberemo smer povezave med dvema uporabnikoma (kdo retvita koga). Barve in številke označujejo skupnosti (1, 2, 3, 4 in 5).

Opazna je jasna delitev med uporabniki v skupnosti 1 in uporabniki v skupnostih 2 in 3. Ugotovitev je pomembna z vidika širjenja informacij, saj nakazuje, da se te lahko učinkovito razširjajo znotraj določenih skupnosti, 62 ne pa prek celotnega omrežja. Komunikacijski vzorci kažejo, da uporabniki na Twitterju v veliki večini delijo vsebine politično/nazorsko podobno usmerjenih uporabnikov, medtem ko je takih povezav s politično drugače mislečimi uporabniki malo.

\section{Razprava}

V okviru $R V 1$ smo se posvetili obsegu slovenske politične razprave pred volitvami v Evropski parlament leta 2019. V njej je sodelovalo 2854 uporabnikov, ki so v obdobju enega meseca skupaj objavili 40670 tvitov (PV1.1). Participacija je neenakomerno razporejena: v povprečju je vsak uporabnik v opazovanem obdobju objavil 14 tvitov, kar 39\% uporabnikov pa zgolj enega; takšna distribucija je pričakovana in skladna s teorijo, po kateri je manjšina, t. i. superudeleženci (Graham in Wright, 2014), odgovorna za produkcijo in razširjanje večine vsebin po družbenih omrežjih (Luarn et al., 2014), tudi na Twitterju (Bruns in Stieglitz, 2013; Bracciale et al., 2018). Med najaktivnejše uporabnike ( $P V$ 1.2) se uvršča veliko v javnem življenju sicer neznanih oseb, med uporabniki z največ vpliva ( $P V 1.2)$ pa je mogoče zaslediti politične stranke, politike in širši javnosti poznane osebe. Najaktivnejši uporabniki niso tudi med najvplivnejšimi uporabniki, kar se sklada z ugotovitvami Bracciale in drugih (2018), ki so politično participacijo na Twitterju preučevali v kontekstu italijanskih parlamentarnih volitev. Participacija v javni razpravi, ki jo spletna družbena omrežja sicer omogočajo vsakemu 


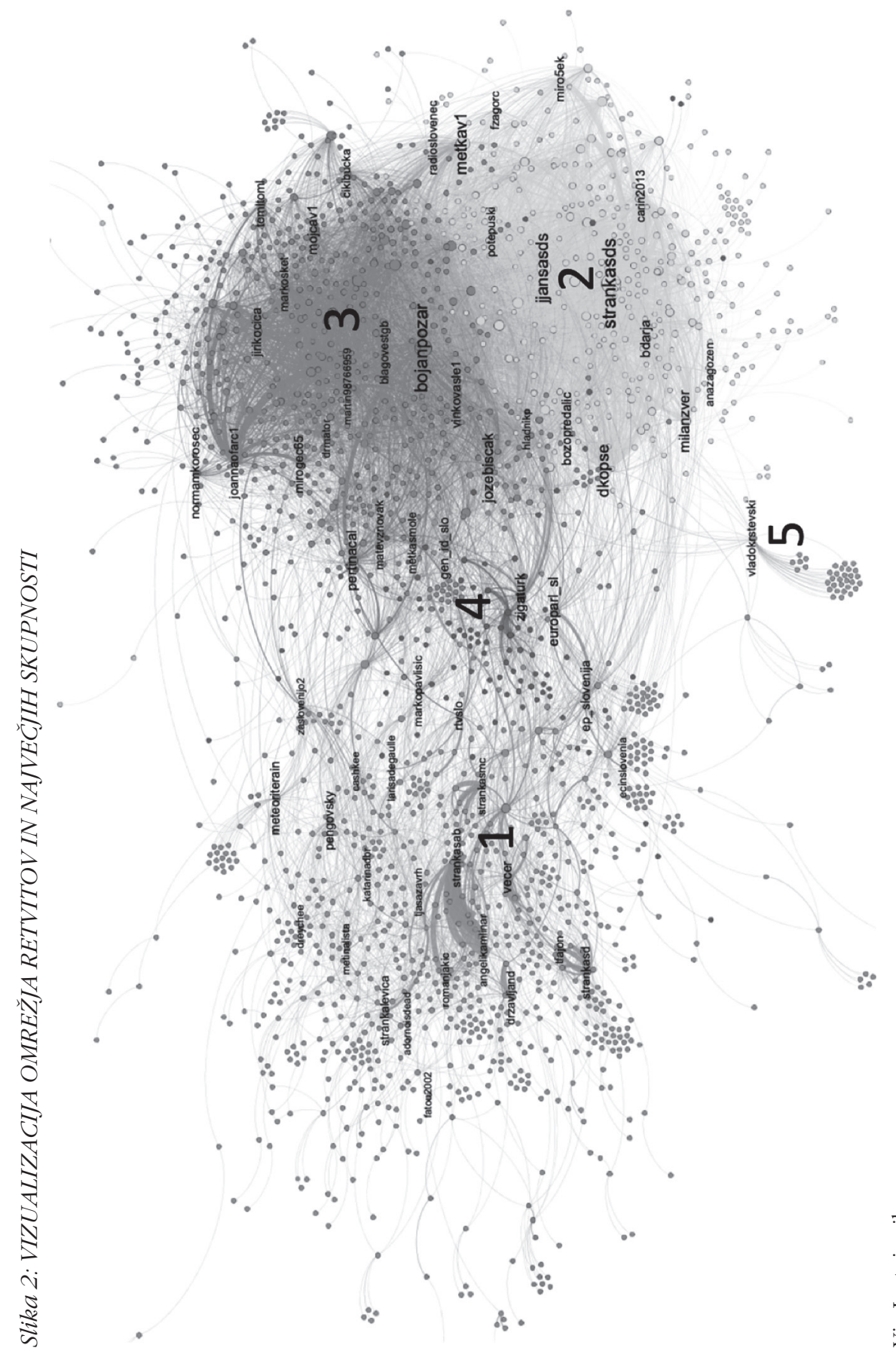


uporabniku, sama po sebi ne prinaša vpliva in vidnosti; $v$ slednjih, tudi na Twitterju, v veliki meri še zmeraj uživajo tradicionalni predstavniki »elit» (Ausserhofer in Maireder, 2013).

Skozi $R V 2$ ugotavljamo, da je slovenska politična razprava na Twitterju razdeljena na posamezne skupnosti. Te so v veliki meri oblikovane na podlagi politične pripadnosti in ideoloških pogledov uporabnikov, kar razkriva pregled središčnih uporabnikov, najpogostejših ključnikov in deljenih vsebin znotraj skupnosti. Med najbolj središčnimi uporabniki posameznih skupnosti (PV 2.1) so pogosto izpostavljeni politiki in profili političnih strank, ${ }^{3}$ med najpogosteje uporabljenimi ključniki pa se pojavljajo oznake strankarskih kampanj. ${ }^{4}$ Analiza uporabnikov in ključnikov razkrije jasno delitev med skupnostjo 1, ki vsebuje levo in levosredinsko usmerjene politične stranke in obsega slabih $40 \%$ vseh uporabnikov, ter skupnostmi 2, 3 in 4, ki vsebujejo desno in desnosredinske politične stranke in skupaj obsegajo dobrih $50 \%$ vseh uporabnikov. Podobne razlike med skupnostmi se kažejo tudi v najpogosteje deljenih povezavah na spletne strani ( $P V$ 2.2). Znotraj različnih delov omrežja se razširjajo medijske vsebine iz različnih virov, pri čemer se povezave na določene spletne strani medijev pojavljajo skoraj izključno med uporabniki ene ali dveh skupnosti. Najočitnejša je razlika med sku64 pnostjo 1 in ostalimi štirimi največjimi skupnostmi v omrežju. V prvi prevladujejo medijske vsebine iz t.i. osrednjih medijev (Večer, STA, Delo ...), pri čemer nekateri izmed njih (npr. Večer) v drugih skupnostih praktično niso prisotni. V preostalih štirih skupnostih so med najpogosteje deljenimi vsebinami povezave do medijev Nova24 in Demokracija, medtem ko je med člani skupnosti 1 deljenje vsebin iz teh virov zanemarljivo. Izsledki potrjujejo teze o fragmentaciji mrežne javne sfere v mnenjsko homogene skupnosti, pri čemer člani različnih skupnosti ne delijo enakih informacij in virov vsebin. To lahko privede do t.i. vzporednih svetov (Mitchell in Weisel, 2014) ali ideoloških odmevnih sob (Sunstein, 2017), ${ }^{5}$ vendar pa bi morebitna potrditev takšne trditve zahtevala poglobljeno kvalitativno analizo deljenih sporočil in vsebin, kar presega okvir te raziskave.

Skupnosti 2 in 3 sta zelo močno povezani med seboj - znaten delež njunih uporabnikov deli vsebine iz druge skupnosti, kar pomeni, da se vsebine pogosto razširjajo med tema deloma omrežja. Kvalitativna analiza najvidnejših vsebin in članov nakazuje, da gre za politično podobno usmerjeni

3 Npr.skupnost 1: @strankaSD; skupnost2: @strankaSDS, @JJansaSDS, skupnost4: @ZigaTurk, @ NovaSlovenija.

4 Npr. skupnost 1: \#zahtevajmoVEČ \#izkušeni \#odločni (SAB); skupnost 2: \#SkupajSmoMočnejsi (SDS in SLS); skupnost 4: \#zaupanje (NSi).

5 Izrazito homogene in izolirane skupnosti uporabnikov, ki nimajo stika z informacijami ali uporabniki izven skupnosti. Zanje je značilna odsotnost nasprotujočih pogledov, kar pogosto privede do radikali zacije in oblikovanja ekstremnih stališč. 
skupnosti. Na drugi strani je skupnost 1 veliko bolj izolirana, saj ima malo povezav s preostalimi deli omrežja. Takšna delitev glede na vzorce komuniciranja sovpada z delitvijo glede na ideološko usmerjenost članov in vsebin v skupnostih. Zanimiv je položaj skupnosti 4 , ki se nahaja na sredini omrežja - njeni člani so med redkimi enotami v omrežju, ki delijo vsebine s skupnostmi tako iz desnega kot tudi iz levega dela omrežja. ${ }^{6}$ Komunikacijski vzorci kažejo, da uporabniki na Twitterju v veliki večini delijo vsebine politično in nazorsko podobno usmerjenih uporabnikov, medtem ko je takih povezav s politično drugače mislečimi uporabniki malo. Sklepamo lahko, da se vsebine hitro in učinkovito širijo znotraj skupnosti, mnogo težje pa onkraj njihovih meja. Struktura opazovanega omrežja spominja na t.i. "polarizirano množico«, ki jo pogosto zasledimo v političnih kontekstih in $\mathrm{v}$ kateri so uporabniki razdeljeni $\mathrm{v}$ strnjene skupine $\mathrm{z}$ malo povezavami med njimi (Smith et al., 2014). To potrjuje teze o fragmentaciji spletnih družbenih omrežij in polarizaciji spletne razprave, $v$ kateri se ustvarjajo skupnosti podobno mislečih uporabnikov, ki preferenčno komunicirajo med seboj in malo (ali pa sploh ne) z drugače mislečimi uporabniki (Sunstein, 2017). Izsledki iz slovenskega okolja se tako skladajo z raziskavami, ki so te procese opazovale $\mathrm{v}$ večjih državah in politično bolj polariziranih kontekstih, npr. ob volitvah v ZDA (Conover et al., 2011), referendumu o izstopu Velike Britanije iz EU (Del Vicario et al., 2017) ali poizkusu odstavitve brazilskega predsednika (Soares et al., 2018).

Empirična analiza uporabe Twitterja v predvolilnem času je prvi korak $\mathrm{k}$ boljšemu razumevanju komuniciranja in pretoka informacij v slovenskih političnih razpravah na spletnih družbenih omrežjih in odpira možnosti za primerjavo ter podobna opazovanja $\mathrm{v}$ različnih kontekstih in časovnih obdobjih. Izsledki lahko služijo kot izhodišče za podrobnejše preučevanje komuniciranja med slovenskimi uporabniki Twitterja. V prihodnosti nameravamo nadaljevati s preučevanjem pretoka informacij med posameznimi skupnostmi, s čimer bi dobili odgovor na vprašanja o tem, ali se v omrežju ustvarjajo t.i. odmevne sobe (Sunstein, 2017). Prav tako bi natančnejša kvalitativna analiza tvitov pomagala jasneje opredeliti značilnosti posameznih skupnosti. Smiselno bi se bilo tudi podrobneje posvetiti središčnim uporabnikom, predvsem njihovi vlogi pri ustvarjanju povezav med deli omrežja ter o vlogi, ki jo imajo politiki; ti bi lahko s strateškim širjenjem vsebin, všečnim njihovim ciljnim skupinam, dodatno spodbujali polarizacijo.

6 Zanimiva je povezava med položajem te skupnosti v komunikacijskem omrežju in kvalitativno analizo njenih najvidnejših uporabnikov in vsebin; med njimi prevladujejo politiki in vsebine stranke NSi, ki se je v kampanji pred opazovanimi volitvami pozicionirala kot sredinsko usmerjena stranka. 


\section{Sklep}

V članku s pomočjo analize omrežij 2867 uporabnikov in 40670 tvitov preučujemo strukturo slovenske politične razprave na Twitterju pred volitvami v Evropski parlament leta 2019. Med najaktivnejše uporabnike spadajo v javnem življenju pretežno neznane osebe, med uporabniki z največ vpliva pa je mogoče zaslediti politike, politične stranke in javno poznane osebe. Na podlagi komunikacijskih vzorcev med uporabniki smo v omrežju identificirali jasno določene skupnosti, v katerih se združujejo uporabniki $s$ podobnimi političnimi pogledi. Znotraj različnih skupnosti se razširjajo medijske vsebine iz različnih virov. Uporabniki na Twitterju v veliki večini delijo vsebine politično/nazorsko podobno usmerjenih uporabnikov, kar nakazuje na fragmentacijo mrežne javne sfere in polarizacijo slovenske spletne politične razprave. Preučevanje toka informacij v mrežni javni sferi je ključno za razumevanje sprememb, ki jih v javno komuniciranje vnašajo spletna družbena omrežja (Bracciale et al., 2018). Izsledki poglobljene empirične analize uporabe Twitterja v Sloveniji pred volitvami v Evropski parlament prispevajo k boljšemu razumevanju političnega komuniciranja na spletu, kar je dobrodošlo v kontekstu razprav o vlogi družbenih omrežij 66 pri spodbujanju polarizacije in oblikovanju zaprtih skupnosti (Bruns et al., 2017). Raziskava prispeva nove empirične podatke o vzorcih širjenja vsebin med slovenskimi uporabniki Twitterja in odgovarja na pozive po preučevanju komuniciranja na spletnih družbenih omrežjih v različnih družbah, jezikih in kontekstih (Bennett in Livingston, 2018).

\section{LITERATURA}

Allcott, Hunt in Matthew Gentzkow (2017): Social media and fake news in the 2016 election. Journal of Economic Perspectives 31 (2): 211-236.

Arlt, Dorothee, Adrian Rauchfleisch in Mike S. Schäfer (2019): Between Fragmentation and Dialogue. Twitter Communities and Political Debate About the Swiss »Nuclear Withdrawal Initiative«. Environmental Communication 13 (4): 440456.

Ausserhofer, Julian in Axel Maireder (2013): National politics on Twitter: structures and topics of a networked public sphere. Information Communication and Society 16 (3): 291-314.

Bakshy, Eytan, Solomon Messing in Lada Adamic (2015): Exposure to ideologically diverse news and opinion on Facebook. Science 348 (6239): 1130-1132.

Barberá, Pablo (2014): How social media reduces mass political polarization. Evidence from Germany, Spain, and the U.S. Job Market Paper, New York University 46.

Barberá, Pablo, John Jost, Jonathan Nagler, Joshua Tucker in Richard Bonneau (2015): Tweeting from left to right: is online political communication more than an echo chamber? Psychological Science 26 (10): 1531-1542. 
Bastian, Mathieu, Sebastien Heymann in Mathieu Jacomy (2009): Gephi: An Open Source Software for Exploring and Manipulating Networks. Proceedings of the International AAAI Conference on Web and Social Media, 361-362.

Bastos, Marco Toledo, Rafael Luis Galdini Raimundo in Rodrigo Travitzki (2013): Gatekeeping Twitter: Message diffusion in political hashtags. Media, Culture and Society 35 (2): 260-270.

Benkler, Yochai (2006): The wealth of networks: How social production transforms markets and freedom. London: Yale University Press.

Bennett, Lance in Steven Livingston (2018): The disinformation order: disruptive communication and the decline of democratic institutions. European Journal of Communication 33 (2): 122-139.

Blondel, Vincent D., Jean-Loup Guillaume, Renaud Lambiotte in Etienne Lefebvre (2008): Fast unfolding of communities in large networks. Journal of Statistical Mechanics: Theory and Experiment 2008 (10): P10008.

Borra, Erik in Bernhard Rieder (2014): Programmed method: Developing a toolset for capturing and analyzing tweets. Aslib Journal of Information Management 66 (3): 262-278.

Bracciale, Roberta, Antonio Martella in Chiara Visentin (2018): From super-participants to super-echoed: participation in the 2018 Italian electoral twittersphere. Partecipazione e Conflitto 11 (2): 361-393.

Brezovšek, Marjan (1995): Politična participacija: prispevek k analizi „participativne demokracije“. Teorija in praksa 32 (3/4): 199-211.

Bruns, Axel (2017): Echo chamber? What echo chamber? Reviewing the evidence. 6th Biennial Future of Journalism Conference (FOJ17), 0-11. Cardiff.

Bruns, Axel in Tim Highfield (2016): Is Habermas on Twitter? Social Media and the Public Sphere. V: Axel Bruns, Gunn Enli, Eli Skogerbo, Anders Larsson, Christian Christensen (ur.), The Routledge Companion to Social Media and Politics, 78-95. New York: Routledge.

Bruns, Axel, Brenda Moon, Felix Münch in Troy Sadkowsky (2017): The Australian twittersphere in 2016: mapping the follower/followee network. Social Media+ Society 3 (4): 2056305117748162.

Bruns, Axel in Stefan Stieglitz (2013): Towards more systematic Twitter analysis: Metrics for tweeting activities. International Journal of Social Research Methodology 16 (2): 91-108.

Castells, Manuel (2008): The new public sphere: global civil society, communication networks, and global governance. The ANNALS of the American Academy of Political and Social Science 616 (1): 78-93.

Cha, Meeyoung, Hamed Haddadi, Fabrício Benevenuto in Krishna P. Gummadi (2010): Measuring user influence in Twitter: The million follower fallacy. Fourth International AAAI Conference on Weblogs and Social Media Associatio.

Conover, M. D., J. Ratkiewicz, A. Goncalves, A. Flammini in F. Menczer (2011): Political polarization on Twitter. Proceedings of the Fifth International AAAI Conference on Weblogs and Social Media Political (133): 89-96.

Dang-Xuan, Linh, Stefan Stieglitz, Jennifer Wladarsch in Christoph Neuberger (2013): An Investigation of Influentials and the Role of Sentiment in Political 
Communication on Twitter During Election Periods. Information Communication and Society 16 (5): 795-825.

Del Vicario, Michela, Alessandro Bessi, Fabiana Zollo, Fabio Petroni, Antonio Scala, Guido Caldarelli, ... Walter Quattrociocchi (2016): The spreading of misinformation online. Proceedings of the National Academy of Sciences 113 (3): 554-559.

Del Vicario, Michela, Fabiana Zollo, Guido Caldarelli, Antonio Scala in Walter Quattrociocchi: (2017). Mapping social dynamics on Facebook: The Brexit debate. Social Networks 50: 6-16.

Dubois, Elizabeth in Devin Gaffney (2014): The Multiple Facets of Influence: Identifying Political Influentials and Opinion Leaders on Twitter. American Behavioral Scientist 58 (10): 1260-1277.

Duggan, Maeve in Aaron Smith (2016): The political environment on social media. Pew Research Center. Dostopno prek http://www.pewinternet.org/2016/10/ 25/the-political-environment-on-social-media/, 29. 10. 2020.

Dylko, Ivan, Igor Dolgov, William Hoffman, Nicholas Eckhart, Maria Molina in Omar Aaziz (2017): The dark side of technology: An experimental investigation of the influence of customizability technology on online political selective exposure. Computers in Human Behavior 73: 181-190.

Ghajar-Khosravi, Shadi in Mark Chignell (2017): Pragmatics of Network Centrality. V: Luke Sloan in Anabel Quan-Haase (ur.), The SAGE Handbook of Social Media Research Methods, 309-327. Sage.

Goel, Sharad, Ashton Anderson, Jake Hofman in Duncan J. Watts (2015): The structural virality of online diffusion. Management Science 62 (1): 180-196.

Graham, Todd in Scott Wright (2014): Discursive Equality and Everyday Talk Online: The Impact of "Superparticipants". Journal of Computer-Mediated Communication 19 (3): 625-642.

Guess, Andrew, Brendan Nyhan, Benjamin Lyons in Jason Reifler (2017): Avoiding the echo chamber about echo chambers. Knight Foundation.

Habermas, Jürgen (1989): Strukturne spremembe javnosti. Ljubljana: Studia Humanitatis.

Harrigan, Nicholas, Palakorn Achananuparp in Ee-Peng Lim (2012): Influentials, novelty, and social contagion. Social Networks 34 (4): 470-480.

Himelboim, Itai, Stephen McCreery in Marc Smith (2013): Birds of a Feather Tweet Together: Integrating Network and Content Analyses to Examine CrossIdeology Exposure on Twitter. Journal of Computer-Mediated Communication 18 (2): 40-60.

Holtzhausen, Derina in Ansgar Zerfass (2015): Strategic communication: Theoretical foundations and progress of the research area. V: Derina Rhoda Holtzhausen in Ansgar Zerfass (ur.), The Routledge handbook of strategic communication, 3-17. New York: Routledge.

Howard, Philip N., Samantha Bradshaw, Bence Kollanyi, Clementine Desigaud in Gillian Bolsover (2017): Junk news and bots during the French presidential election: what are French voters sharing over Twitter? V: Comprop Data Memo. Dostopno prek https://comprop.oii.ox.ac.uk/research/junk-news-and-bots-dur- 
ing-the-german-parliamentary-election-what-are-german-voters-sharing-overtwitter/, 16. 10. 2020.

Jacomy, Mathieu, Tommaso Venturini, Sebastien Heymann in Mathieu Bastian (2014): ForceAtlas2, a continuous graph layout algorithm for handy network visualization designed for the Gephi software. PLOS ONE 9 (6): e98679.

Jungherr, Andreas (2015): Analyzing political communication with digital trace data. Cham: Springer.

Klinger, Ulrike in Jakob Svensson (2015): Network Media Logic: Some Conceptual Considerations. V: Axel Bruns, Gunn Enli, Eli Skogerbo, Anders Larsson, Christian Christensen (ur.), The Routledge Companion to Social Media and Politics, 23-38. New York: Routledge.

Lehmann, Janette, Bruno Gonçalves, José J. Ramasco in Ciro Cattuto (2012): Dynamical classes of collective attention in Twitter. WWW'12 - Proceedings of the 21st Annual Conference on World Wide Web, 251-260.

Luarn, Pin, Jen-Chieh Yang in Yu-Ping Chiu (2014): The network effect on information dissemination on social network sites. Computers in Human Behavior 37: $1-8$.

Maireder, Axel, Brian E. Weeks, Homero Gil de Zúñiga in Stephan Schlögl (2017): Big data and political social networks: introducing audience diversity and communication connector bridging measures in social network theory. Social Science Computer Review 35 (1): 126-141.

Miller, McPherson, Smith-Lovin Lynn in M. Cook James (2001): Birds of a Feather: Homophily in Social Networks. Annual Review of Sociology 27: 415-444.

Mitchell, Amy in Rachel Weisel (2014): Political Polarization and Media Habits. V: Pew Research Center. Dostopno prek https://www.journalism.org/2014/10/21/ political-polarization-media-habits/, 8. 10. 2020.

Neudert, Lisa Maria in Nahema Marchal (2019): Polarisation and the use of technology in political campaigns and communication. Bruselj: Evropski parlament.

O'Connor, Amy in Michelle Shumate (2018): A Multidimensional Network Approach to Strategic Communication. International Journal of Strategic Communication 12 (4): 399-416.

Oblak, Tanja (2014): Paradoksi in transformacije demokracije, državljanstva in participacije v digitalni dobi. Teorija in Praksa 51 (6): 1165-1184.

Pariser, Eli (2011): The filter bubble: what the internet is hiding from you. London: Penguin UK.

Rasmussen, Terje (2016): The Internet Soapbox: Perspectives on a Changing Public Sphere. Oslo: Universitetsforlaget.

Ruiz-Soler, Javier (2018): The last will be the first: a study of European issue publics on Twitter. PArtecipazione e COnflitto - The Open Journal of Sociopolitical Studies 11 (2): 423-447.

Sekloča, Peter (2020): Ohranjanje zaupanja v mrežni javni sferi: Problem javnih forumov in personalizacija novic. Teorija in Praksa 57 (1): 308-325.

Shin, Jieun, Lian Jian, Kevin Driscoll in François Bar (2017): Political rumoring on Twitter during the 2012 US presidential election: Rumor diffusion and correction. New Media and Society 19 (8): 1214-1235. 
Smith, Marc A., Lee Rainie, Itai Himelboim in Ben Shneiderman (2014): Mapping Twitter Topic Networks: From Polarized Crowds to Community Clusters. The Pew Research Center. Dostopno prek http://www.pewinternet.org/2014/ 02/ 20/mapping-twitter-topic-networks-from-polarized-crowds-to-community-clusters, 16. 10. 2020.

Soares, Felipe Bonow, Raquel Recuero in Gabriela Zago: (2018): Influencers in polarized political networks on Twitter. SMSociety '18: Proceedings of the 9th International Conference on Social Media and Society, 168-177.

Spohr, Dominic (2017): Fake news and ideological polarization. Business Information Review 34 (3): 150-160.

Stewart, Leo Graiden, Ahmer Arif, A. Conrad Nied, Emma S. Spiro in Kate Starbird (2017): Drawing the Lines of Contention: Networked Frame Contests Within \#BlackLivesMatter Discourse. Proceedings of the ACM on Human-Computer Interaction 1 (CSCW): 1-23.

Strömbäck, Jesper in Frank Esser (2014): Mediatization of Politics: Towards a Theoretical Framework. V: Frank Esser in Jesper Strömbäck (ur.), Mediatization of Politics: Understanding the Transformation of Western Democracies, 3-28. London: Palgrave Macmillan.

Stromer-Galley, Jennifer (2017): Political Discussion and Deliberation Online. V: Kate Kenski \& Kathleen Hall Jamieson (ur.), The Oxford Handbook of Political Communication, 837-851. Oxford: Oxford University Press.

70 Sunstein, Cass (2017): \#Republic: Divided Democracy in the Age of Social Media. Oxford: Princeton University Press.

van Dijk, Jan A. G. M. in Kenneth L. Hacker (2018): Internet and democracy in the network society. New York: Routledge.

van Ruler, Betteke (2018): Communication Theory: An Underrated Pillar on Which Strategic Communication Rests. International Journal of Strategic Communication 12 (4): 367-381.

Verčič, Dejan, Ana Tkalac Verčič in Krishnamurthy Sriramesh (2015): Looking for digital in public relations. Public Relations Review 41 (2): 142-152.

Verhoeven, Piet, Ansgar Zerfass, Dejan Verčič, Ralph Tench in Angeles Moreno (2018): Public relations and the rise of hypermodern values: Exploring the profession in Europe. Public Relations Review 44 (4): 471-480.

V Vike-Freiberga, Vaira, Herta Däubler-Gmelin, Ben Hammersley in Luís Miguel Poiares Pessoa Maduro (2013): A free and pluralistic media to sustain European democracy. High Level Group on Media Freedom and Media Pluralism. Dostopno prek http://ec.europa.eu/digital-agenda/sites/digital-agenda/files/ HLG Final Report.pdf, 12. 11. 2020.

\section{VIRI}

Statistični urad Republike Slovenije (2019): Uporaba interneta v gospodinjstvih in pri posameznikih. Dostopno prek https://www.stat.si/StatWeb/News/Index/ 8423, 29. 10. 2020. 
Eurostat (2019): Individuals - internet activities ISOC_CI_AC_I. Dostopno prek https://ec.europa.eu/eurostat/databrowser/view/isoc_ci_ac_i/default/table? lang=en, 29. 10. 2020.

Valicon (2020): Uporaba družbenih omrežij in storitev klepeta v Sloveniji 2018 2019. Dostopno prek https://www.valicon.net/sl/2020/01/uporaba-druzbenihomrezij-in-storitev-klepeta-v-sloveniji-2018-2019/, 29. 10. 2020. 